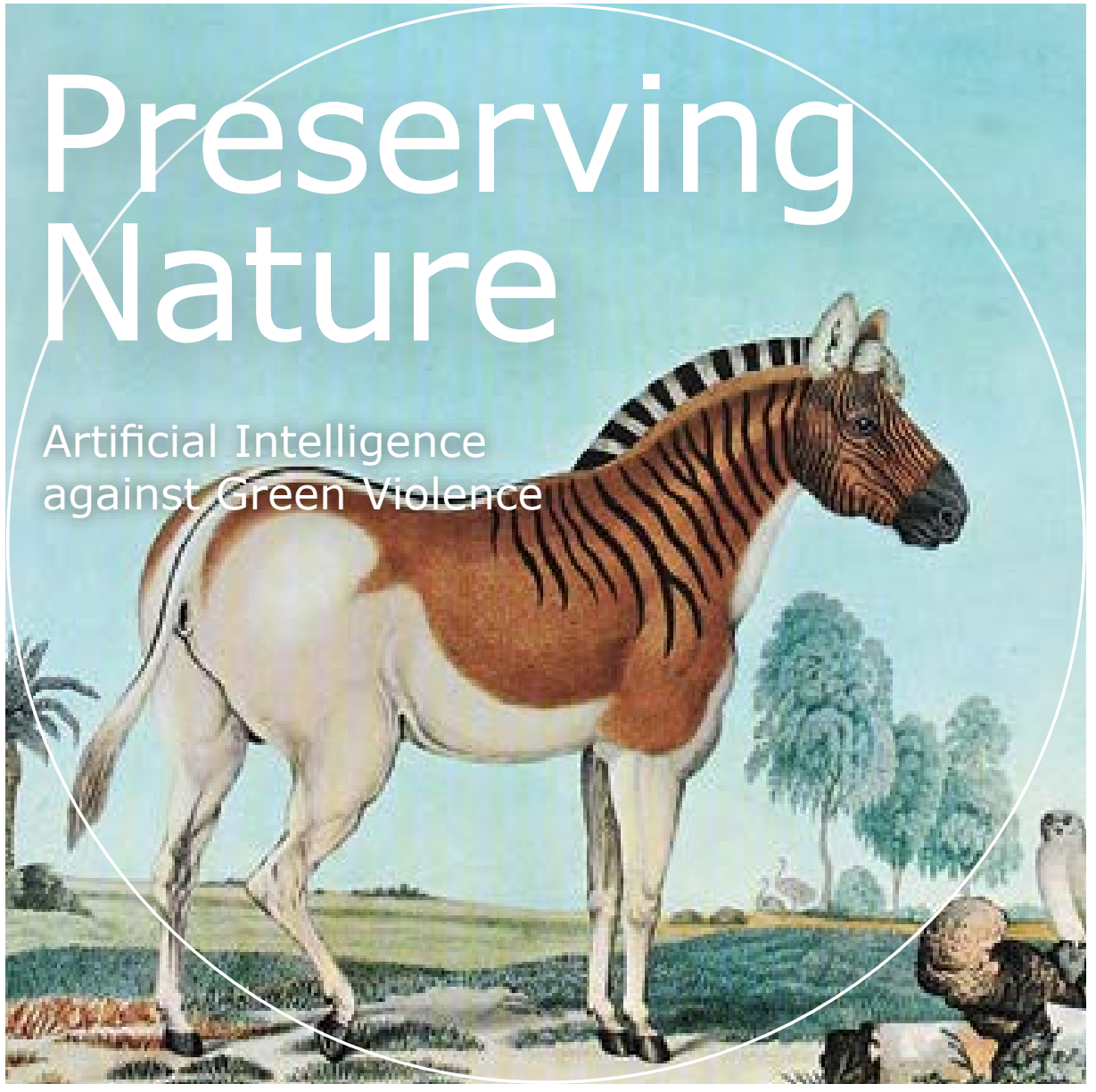

Prof.dr Herbert H.T. Prins

Farewell address upon retiring as Professor of Resource Ecology (formerly Nature Conservation in the Tropics and Vertebrate Ecology) at Wageningen University \& Research on 31 October 2019 



\section{Preserving Nature: Artificial Intelligence against Green Violence}

\section{Prof.dr Herbert H.T. Prins}

Farewell address upon retiring as Professor of Resource Ecology (formerly Nature Conservation in the Tropics and Vertebrate Ecology) at Wageningen University \& Research on 31 October 2019. 
DOI $10.18174 / 514745$

ISBN 978-94-6395-315-3

@2019 H.H.T. Prins. All rights reserved. No parts of this publication may be reproduced by print, photocopy, stored in a retrieval system or transmitted by any means without the prior written permission of the author. 


\section{Preserving Nature: Artificial Intelligence against Green Violence}

Ladies and Gentlemen, Esteemed Colleagues, Students,

Standing here, I feel kinship with a man who defended on this exact date his views and beliefs against fierce opposition of other men who - with tooth and claw defended their views and beliefs. I refer to Martin Luther who some five hundred years ago nailed his 95 theses (i.e., propositions) challenging the Roman Catholic Church to the door of the University of Wittenberg in Germany [1].

Luther was a professor of moral theology, especially in the field of 'good and evil' [2]. I am a professor of ecology, not of theology, but - yet - I also want to focus on 'good and evil', but in nature conservation. I will deal with poaching and anti-poaching activities. I will focus mainly on the poaching of elephants and rhinos - and toward the end of this lecture I will discuss how artificial intelligence offers an opportunity to develop predictive poaching analytics that could significantly diminish wildlife crime.

Martin Luther was born in 1483 . He became a lecturer at the age of 25. At that age, I had not even received my Master's title but had participated together with quite some other international students in the Revolução dos Cravos (the 'Carnation Revolution'; in Dutch, the 'Anjerrevolutie') in Portugal [3]. When Luther nailed his propositions to the door, he was 34 , and from that moment, he was in the middle of the fray of religious controversy and had to fight, perhaps literally, for his views and for his life. When I was 34, I was in the East African bush doing research for my $\mathrm{PhD}$ and stumbled into another kind of fray. While it wasn't as dramatic as Luther's, there were times when I, too, had to fight for my life. Luther's freely published words and free thinking led to the religious wars that racked Europe and cost millions of people their lives. Land abandonments played havoc with farming and ecology; indeed, in perhaps $30 \%$ of the land reverted to bush during the religious wars at the end of the 
Middle Ages. Forests reappeared, and undoubtedly, in many places wolves and moose came back [4]. Similar things had happened in East Africa, with much land abandonment and bush encroachment; I will come to that later. At present, we would call this 'rewilding' - some of us would consider that to be 'good' and others 'evil'. Likewise, some see conservation as 'good' and poaching as 'evil'. During my professional years, I discovered that it's not that simple.

\section{Pax Britannica and the proliferation of poverty}

Tanzania, the East African country where I chose to live in the early 1980s, was in a state of upheaval at the time, nearly two decades after gaining independence from colonial rule [5]. There were unexpected parallels with Europe after the religious hostilities of the 16th and 17th century. The Cold War raged, and Tanzania was in the Socialist Camp. The rhetoric was anti-colonial, which led to very intriguing historical insights. I became aware that the famous Pax Britannica, the Peace brought by Great Britain to Africa at the end of the 19th century [6], was a misconception or misnomer. Indeed, with the advance of European civilization, a shockwave of alien diseases decimated local populations of people as well as animals. A cascade of events followed: In many areas, bush came back (which is termed 'bush encroachment'), and in that bush tsetse flies established themselves. Then sleeping sickness spread, which precluded land reclamation. This led to a rapid increase in wildlife in places where people could not live anymore [7]. Then, the destruction of local agriculture along with the spreading of the alien rinderpest disease among cattle and other ungulates led to massive starvation of people [8]. Tribal warfare became rampantnot because the indigenous peoples were uniquely pugnacious but largely due to the convulsion caused by colonialism. Indeed, many protected areas now known as wildlife paradises were previously agricultural. Even the famous Ngorongoro Crater or the Serengeti [9]!

In short, from the very early beginnings of the colonial era onward, nature took over vast regions formerly devoted to farming and pastoralism, at the cost of local people [10]. Please keep this in mind during the rest of my lecture, as I delve deeper into the vicissitudes of 'good' and 'evil' in relation to protecting wildlife against poachers. I hope you will be cautious or even wary about jumping to conclusions concerning questions of who or what is good or evil. Not everyone views wildlife with reverence. When you have seen a grandfather rocking his lifeless granddaughter in his lap after she has been torn from bed and trampled by a marauding elephant, or were shouted at by a despaired woman who saw her neighbour being killed by a bear and then the daughter too before her own eyes [11], you also may get a blurred image of who is 'good' and who is 'evil'. 


\section{Socialism, more poverty and economic sabotage}

During those last years of the Cold War in Tanzania, the East German secret police read my private correspondence. Telephone calls had to be booked days in advance, and the Dutch Embassy curiously informed me and the few other Dutchmen living 'upcountry' by telegraph that 'in case of an earthquake (read: military coup) the Dutch authorities cannot do anything for you and you'd better stay on good terms with your neighbours'. My closest neighbour was a Scottish lady at four hours' drive [12]. There were secret army camps where one was not supposed to go to. In the South, the freedom fighters of the South African ANC and the Zimbabwean ZANU had their camps where, in the name of freedom, unsavoury things were done. The country was so unstable that when the prime minister was killed in a car accident, it was rumoured that the ANC had done it [13]. Poverty was rampant, people walked in rags or even naked, police roadblocks were everywhere, and thousands of people were arrested for alleged economic sabotage or racketeering. If one had more than one litre of kerosene or one bar of soap, one could be imprisoned for six months. However, in the name of science and for the pursuit of a doctoral degree, I stayed on in the bush, far removed from civilization in the midst of a national park, with only some kerosene lamps, my typewriter and my personal staff.

Because of the government's impecuniosity, I found myself shouldering numerous responsibilities to maintain the park, in particular providing food and shelter for its rangers. Then, Tanzania got engaged in the Uganda War to oust the human rights violator Idi Amin [14]. After that war, suddenly I had 10 additional men to feed young traumatized soldiers who were given park ranger jobs but for which the Government had no money to spend [15]. My household thus grew to 16 men, all of them heavily armed. Finding and buying enough food to feed them was not easy, so I started black marketing, engaged in smuggling food and bribing the military for fuel necessary to transport men, food and other supplies. It became a very murky world in which I had to maintain myself.

The widespread poverty, the denunciation of the values of the former colonialist powers, the dwindling morale of unpaid national parks rangers and underpaid bosses, plus the lack of education of the appointed political party men and women in leading positions led to a fatal breakdown of the national parks system. Rampant poaching of wildlife started. Some claim it began with the military taking up illegal hunting to feed army camps. Others say it started with rangers shooting game to feed themselves, or with poor peasants claiming their due for usurped lands where their fathers or grandfathers had farmed. Whatever the cause, it started. And witnessing its effect, I was dragged into nature conservation. 
Men in my burgeoning camp household were loyal to me as I continued to feed them and made sure that they got their medicines - and sometimes helped them out with family crises. I forbade the use of alcohol in my camp for their safety and my own as well as that of the wildlife we were charged with protecting. I was becoming increasingly engaged in organizing anti-poaching work. I figured that enough other people would deal with social injustice, disenfranchisement, poverty control, etcetera. As a field biologist, I was in a position to give attention to the plight of the Black rhino and the African elephant. I can tell you now that we could safeguard a reasonable proportion of Manyara's elephants, but the price of rhino horn relative to its size was much more attractive than ivory, which made rhinos all the harder to protect. We lost them all [16].

And then I discovered that this poaching was organized by the very top-personnel of Tanzania National Parks [17].

\section{Corruption can take place in any organisation}

I was on friendship terms with my own rangers, and they started feeding me information - including what is known as 'hot information'. Indeed, it was so hot that the highest government official in charge of nature conservation warned me for my own safety. He told me that it would be wise to leave the country a.s.a.p. because he could no longer guarantee that I would not be killed 'accidentally' by a stray bullet [18].

I can assure you that I felt unnerved; I also felt very lonely. All other foreign scientists that I knew had left the country because life had become too difficult without food and without fuel [19]. A good friend who worked in the Ngorongoro Crater also discovered high officials involved in rhino poaching, and she had also been warned. When she did not listen, indeed, bullets were fired at her. She then took a long holiday. Conservationists in neighbouring Kenya got killed.

Around this time, Royal Dutch Shell started exploring for oil and gas in southern Tanzania's vast Selous Game Reserve. Seismic lines were cut through the bush, making the area accessible for poaching: African teak wood left the country by the train load via the new Chinese-built railway. Within about five years, Black rhinos were exterminated there, and some 40,000 elephants were killed [20].

Intriguingly, the Selous Game Reserve had been an area where tens of thousands of people had lived before the anti-German Maji-Maji Rebellion. They left due to massive retaliation by the colonial masters of the day and their forced resettlement after the rebellion [21]. The number of rhinos and elephants had increased enormously 
on these former agricultural lands [22]. However, by the 1960s elephants and rhinos had disappeared from all other lands already through colonial elephant control officers - some officers had individually shot more than 10,000 in a lifetime [23]! During the colonial era, such wholesale slaughter was viewed positively as part of an effort to make the land fit for agriculture. But in the 1980s, people of the former colonial powers (that is: us) saw the widespread killing of elephants as a disaster - in part due to the tourism revenue these magnificent animals helped to generate but also because the concept of 'intrinsic value' became important. The killing was termed 'poaching' and became forcefully counteracted by government services often assisted by western NGO's. The Ivory Wars [24] had started, and this led to a strengthening of the conservation movement - first in Kenya and later elsewhere in Africa. However, there were some who branded anti-poaching activities as 'Green Violence'.

\section{Can anti-poaching activities be equated with Green Violence?} What is 'Green Violence'? Not everyone sees this as a correct term. The basic observation is that force is used by organizations or individuals to protect nature. Indeed, professor Büscher of this University defined 'Green Violence' as 'the deployment of violent instruments and tactics towards the protection of nature' [25]. However, does 'force' or an 'armed reaction' equate with the noun 'Violence'? Violence is defined in the Oxford Dictionary as 'Behaviour involving physical force intended to hurt, damage, or kill someone or something' - so it is the intent to hurt or kill that differentiates 'violence' from 'physical force'. Secondly, the Oxford Dictionary defines 'violence' as 'The unlawful exercise of physical force or intimidation by the exhibition of such force'. So, the term 'Green Violence' puts emphasis on the idea that the use of physical force to protect nature is executed unlawfully and with the intent to hurt. This is different from a similar term, namely, ‘Green Militarization' [26].

Most of us believe that lawful governments that are democratically in control of their military and police, have the 'monopoly on the exercise of physical force' - in Dutch 'de monopolie van geweld'. Professor Gribnau of Leiden University summarized this well in his oration of 2008, which I translate: 'The State seeks the monopoly of exercising physical force to prevent citizens taking the law into their own hands (also known as frontier justice) and to maintain security. This authority aimed at making laws and maintaining them is only possible if and when the State has that monopoly on the legitimate use of force'. [End Quote.] [27]. This is a central tenet of sovereignty of a state or of a people. If one accepts the government of Kenya, say, or the government of South Africa, as sovereign like that of The Netherlands, and if these governments authorize their services to use physical force to combat poaching, then the term 'Green Militarization' may be a correct one. However, to justify the term 'Green 
Violence' one must make it believable that the physical forces that are used to combat poaching by government services or authorized private services are either unlawful or have the intention to harm. In the former case, authorities must investigate and lay criminal charges. In the latter case, authorities must investigate and use disciplinary control measures.

My understanding so far was that when poachers were arrested in Tanzania, or if shoot-outs occurred, the formal procedures were clear: the cases always must be investigated by police and taken to court. Much more serious, of course, is when the formal procedures are not followed, and frontier justice is carried out. It is then, of course, irrelevant whether 'Green Violence' has been carried out by government services or by otherwise authorised security companies. I will come to this later.

There is more disagreement between many nature conservationists and many social scientists. Indeed, quite a number of social scientists appear to contest the ownership or the legality of the ownership of plants, animals and land by a government or by non-local people. They support the notion that wildlife and land are owned by local people. If they are right, then local people are not poachers when they take wildlife that, by right, is theirs. I will come back to this later too.

\section{Green violence vs. Green policing}

But first I want to take you back to the Tanzania in which I was threatened to receive a stray bullet. What was the issue my rangers reported to me? In the nearby Serengeti, many poachers were being killed, and the highest-ranking man of Tanzania's protection agency linked to their deaths was reporting the news with pride to the country's president. Also, outside NGOs were speaking about it with pride and pleasure.

Here's what happened: Rangers of the Serengeti were instructed to go cattle raiding in Sukumaland just south of the Serengeti. The cattle were then driven through the Serengeti to the Tanzania-Kenya border. The border patrols of both countries had been instructed to abandon their posts. These orders had come from that 'highest man' I referred to, whose brother happened to be a high-ranking official on the Serengeti's Kenyan side and who ordered the same at that side so that the cattle could be sold in Nairobi. When the legal owners of the cattle pursued the rangers to try to take back their own cows and bulls, they were shot, and reported as poachers that were legally killed in a shoot-out between the forces that fought at the 'good side' against the evil men of the 'bad side'. Professor Büscher of our University would, undoubtedly and correctly, classify this as 'Green Violence'. 
Because I was privy to this, I was informed that I should leave to save my skin. The highest man in the nature conservation department threatened to have me shot if I would not.

But the incident made me feel all the more drawn into the conservation effort. I started planning anti-poaching patrols myself. I even walked patrols with rangers, and at least twice was present when 'my men' arrested rhino or buffalo poachers. There I experienced something very different than what had transpired in the Serengeti: When we laid out an ambush and poachers walked into our trap, there was no violence. After the arrest, poachers and rangers often smoked a cigarette together, and I transported them in my Land Rover to headquarters, sometimes stopping en route for a break at my camp. It didn't take long to learn that the poachers were not from the dangerous syndicates that one hears about. They were local farmers and youths seeking meat and money because they were hungry and poor [28]. Typically, after an arrest and a court hearing, they were released on bail that would have been a few euros at the time [29]. Because the rangers were armed, we could classify this as 'Green Militarization' but in reality it was much more like ordinary police work and the rangers used their rifles and guns only for warning shots to deter dangerous elephants [30].

If this is 'Green Policing', what is then the right of the state to mark off a national park and deny local people access to the area or deny them the right to harvest meat or trophies such as elephant ivory or rhino horns? That, of course, depends on which state one is working in: a sovereign state makes laws and rules that apply. These laws and rules may be different from other states, and perhaps one does not like the laws and rules of the state one lives in, or one does not like those of another society. But that doesn't give one the right or the power to disregard these laws and regulations.

\section{Poaching is merely equal to theft and not necessarily a heinous crime} In many countries, such as Tanzania and Kenya wild animals are owned by the state, whether they roam on public or private lands: they are not free-for-all. Poaching is thus an economic crime (theft, felony, larceny), namely stealing from the owner, which is the state. Because stealing is considered a crime against property and the state has the monopoly on deploying physical force, the act to defend its ownership forcefully is legal. Thus, one cannot classify that simply as 'Green Violence' - it is merely 'Green Policing' when done according to law.

In other countries, such as South Africa, the state owns the wild animals in its national parks and the choice to defend its property against illegally killing and 
taking ownership of the bounty is thus legal. Where private property is involved, the landowner owns the wild animals there and can, under specific conditions, also defend them as property by taking anti-poaching measures. The legality of this has been tested in court numerous times, and I do not know of cases where a defendant was released after an arrest because it was judged by the court that a defendant had the right to take animals that did not belong to him or her. In other words, antipoaching activities to defend one's property are legal under the condition that everything is done by the book and can be evaluated by a court.

However, one may take the position that the land with its wild animals and wild plants was acquired unlawfully. An often-heard argument is that colonial authorities took the land from indigenous people to establish, for instance, a hunting reserve for the colonial elite. Often, such hunting reserves later became strictly protected areas. When I worked in Tanzania and later in Kenya, I investigated this. If one goes through the colonial administration, a different picture emerges, namely, a drawnout process of 'extinguishing native rights'. Basically, this meant that an administrator together with the community estimated the annual economic yield of an area. Once that yield was agreed upon, the annual financial value was established and, again, agreed upon. After that, the compensation value for the community was set at ten times that annual financial value. In the Netherlands this has been named 'compensatie na onteigenen ten behoeve van rechtmatig overheidshandelen', so expropriation with compensation after lawful or legitimate government action.

Some western NGOs, in particular Oxfam have supported local people in court in East Africa who challenged the legitimacy of this colonial era procedure. This received some traction at lower courts in Tanzania, but the Tanzanian High Court did not find fault with the procedure and ruled, for instance, that Mkomazi National Park had been established lawfully.

In other countries, sometimes expropriation was done without compensation. This led to some successful land claims that restored land to original communities. This has happened in South Africa. However, the procedure to date is that the protection status of the land is maintained. So, national park land with its wildlife becomes a contractual national park for which the local community gets a financial fee. Hence, wildlife protection continues to be lawful.

But is the practice of anti-poaching activities always legitimate? The answer is, of course, 'no' - just as the police can arrest someone lawfully but may use illegitimate practices like a police neck hold (unlawful in the USA but not in the Netherlands). 
It is thus illegal to take unlawful possession of protected wildlife also if that taking into possession takes place in areas that previously were owned by ancestors: descendants do not have legal rights on wild animals or plants that are not theirs. Their economic status - so whether they are poor or not - is not considered relevant, and subsistence hunting on the land of someone else or of the state is judged poaching.

\section{Hard lessons from Tanzania: an undesired reality check}

Back to Tanzania, where the high-ranking government official in charge of nature conservation threatened that I would meet a stray bullet because I had discovered too much about illegal practices masquerading as anti-poaching activities. The threat did cause me to consider giving up my research, but my rangers convinced me to not do that. I knew that one reason they stood in solidarity with me was that I had secured new uniforms, underwear, boots and mosquito nets for 600 rangers all across Tanzania. This was accomplished through extraordinary support from His Royal Highness Prince Bernhard, the Dutch army and KLM [31]. I knew they had my back because I had theirs, but how does one protect oneself against a bullet? I needed to neutralize the man who'd threatened me, but since I do not condone violence, I found another way: I had him removed from office through a direct link I had with the President. From this an important message arises, and that is that people who do anti-poaching activities may themselves meet violence. In other words, 'Green Violence' may be an elicited action that is brought about by violence by criminals.

Yet it is fallacious to assume that poachers are always criminals and because they are criminals, they always will use violence directed against you. That is, literally, a vital mistake. One should realize that many poachers are arrested for reasons that you and I not necessarily rate as criminal. For instance, in Kruger National Park about $75 \%$ of all arrests are of boys and young men, typically between 15 and 18 years of age who fish in the protected area [32].

Yet, how certain can the law-enforcer be that arresting such a fisher will be nonviolent?

I experienced an answer to this question in Indonesia, where I became a national parks planner. On one occasion, surveying the coast of Alas Purwo off Java, my colleagues and I came close to the boat of locals who were fishing illegally over a protected coral reef. Instead of throwing illegal dynamite into the water to stun and kill the fish, these fishermen threw the dynamite at us [33]. This is the situation that a law-enforcer fears: poachers using violence. That is, I think, very different from the 
law-enforcing situation that I had grown to view as acceptable in Tanzania, namely, an arrest of trespassing local people by rangers in which both parties refrain from violence.

The experience of fishermen throwing dynamite at me in Indonesia taught me that poachers could use violence to defend their livelihood. And the experience of someone threatening to have me shot in Tanzania taught me that criminals could masquerade as anti-poachers. Both cases also taught me one should not be too easily scared.

\section{Developing a world view not based on Western European creed} As regular professor at this university, I have tutored scores of PhD students from countries outside the Netherlands. They have been a tremendous source of information for me because many of them were professionals from protected area services. I have had the privilege of doing fieldwork with many of them in some of the most remote areas on Earth. With them, I learned much about corruption among police officers and corrupt rangers. I learned much about illegal practices through joining patrols, for example, along the Kenya-Somalia border, and the China-Russia border, as well as when camping in the forests of Cameroon or Nepal, traveling by boat in Siberia, walking across rainforests in Sumatra, and driving cross-country in the savannas of Tanzania. Nearly everywhere, wildlife is so seriously threatened, land conversion is so fast and sweeping and legal and illegal trade in wildlife is so rampant that one is tempted to envision a colossal conspiracy against the Planet's biodiversity. I have learned that the world hardly operates along the principles enshrined in the high morality that one would like to see actions elsewhere imbued with. Alas! It is not so.

Ladies and Gentlemen! If such a conspiracy can seem plausible, perhaps masterminded by 'the Chinese' or 'the Americans' or 'the Mafia', one should not be amazed if some people react by justifying the use of violence to protect innocent animals. This is what Rob Fletcher of our University addressed in a recent paper: the idea that radicalized people believe its defensible to use violence to redress violence [34].

The problem, of course, is to find evidence for those masterminds. Yet, one should realize that if one subscribes to the idea that rhino poaching is controlled by leaders of 'syndicates', and if in reality these syndicates do not exist, one can waste an enormous amount of time and energy barking up the wrong tree. Evidence of such syndicates is nearly non-existent. Trade networks for animal parts, including rhino 
horn, seem to be little more than regular social networks through which goods find a buyer. Indeed, Adam Smith's invisible hand appears to be that mastermind of poaching. There is equally little evidence for gangs that use mortal violence against law-enforcers. The African poaching gangs have little in common with the often psychopathic criminals of the American gang literature [35]. Yet, in the discourse 'we - who are good' vs. 'them - who are bad' it would be so convenient if 'they' were indeed 'bad' and 'they' existed as a group. I fear that this is our old-fashioned primate brain taking over when we think like that.

\section{Midway perspective: wildlife protection can rarely be equated with violence}

It is now time to sort the things out:

1.If a sovereign government allows physical force, then that must be accepted as lawful and legal. If duly authorized government services exert that force then that can be lawful and legitimate.

2. If it is legal in a sovereign State that wildlife is owned, either by the state itself or by private owners, then the unauthorized taking of that wildlife by someone who is not the owner, is considered theft. Theft is nearly everywhere on Earth a violation of the law.

3. Wildlife theft in most countries falls under civil law (it is tort, not crime). However, if severely threatened species, such as various rhino species, are killed illegally, it can become a crime.

4. In nearly all countries, the use of firearms without a permit is considered a crime punishable by the state.

5. Most elephant and rhino poaching is done using firearms.

6. Some poachers use violence against those who hinder their illegal hunting.

7. Some anti-poaching personnel, whether in private or government service, have reacted by militarization, even though their work is more like that of a security company or of the police.

8. Some anti-poaching personnel, whether in government or private service, have engaged in illegitimate or even unlawful violence. 
From this it follows that equating anti-poaching activities with 'Green Violence' is hardly ever justified. One should keep her or his vocabulary correct. By framing anti-poaching as 'Green Violence' one may actually undermine public support for nature preservation. The good side of the use of the term, however, is that it draws attention to the moral standard that also in nature preservation the end does not justify all means.

I now would like to turn to the concept of 'gangs' and especially of 'criminal gangs', along with the question where the guns come from.

\section{Weapons and violence}

A few months ago, I had the sublime pleasure of visiting Lake Turkana in north-west Kenya with some Kenyan PhD students [36] We received permission to use a large, green Kenya Wildlife Service Toyota Land Cruiser, with radio aerials. It looked militarized. While we drove through the Chalbi Desert four things struck us. First of all, the gazelles we saw fled immediately when they perceived our vehicle. Second, we hardly saw any wildlife, not even in the strictly protected area of Sibiloi National Park. Third, when young girls herding goats saw our vehicle, they bolted as if fleeing for their lives. Fourth, every local man from the age of 15 carried a firearm. In the park, rangers with machine guns and bullet-proof vests protected me from local pastoralists, who had created grazing space for their livestock by eradicating nearly all local wildlife in the national park. A few days later, when sleeping in some little oasis hut, I heard shooting. The next morning, two young local men lay dead nearly on my stoep. Other pastoralists had shot them for attempting to steal goats [37].

Significantly, in the many thousands square kilometres of borderlands shared by South Sudan, Ethiopia and Kenya, the last place where one can see unmolested Burchell's zebras and Tiangs is around one single ranger post, where rangers make their rounds toting heavy-duty guns and wearing bullet-proof vests. It is also the only place where law-and-order is maintained. I had experienced the same along the Kenya-Somalia border, and also in North Cameroon, where local nature conservation is in conflict with Boko Haram. Perhaps we see that wrongly, and possibly local members of Boko Haram merely consider the local wildlife as a resource, as generations have before them. But often they take those resources with firearms, and apparently do not hesitate to open fire on conservationists. Along the border with Somalia, fingers are pointed in the direction of Al-Shabaab, and we are made to believe that because their members are terrorists they spread weapons. Yet, perhaps one should realize that the armed conflict between the Somali Al-Shabaab and the 
Kenyan Armed Forces is largely about who can tax the illegal export of charcoal [38]. Moreover, one should know that Peacekeeping is a very lucrative business model for many armed forces [39]. And for that business model to work, one should realise that insecurity is the product that is exploited.

When I started investigating the situation around Lake Turkana in northern Kenya, I found out that some 900,000 Turkana live in this area and 200,000 or so are men beyond the age of 15 years. About the same number of men live on the other side of the borders. Intriguingly, Sudan's government doled-out 250,000 guns, Ethiopia's about 100,000 and a former President of Kenya distributed another 100,000. Thus, these governments supplied two firearms for every adult man in this region [40]. Wealthy businessmen fund Al-Shabaab, and firearms sold by China, Russia and the West continue to pour in across the Red Sea. Likewise, in West Africa and in Central Africa. It is now estimated that in the whole of Africa, $80 \%$ of all firearms are in private hands. During the Cold War, literally millions of small firearms were shipped to Africa to fuel wars in countries like Mozambique or Angola, and when the Cold War was over, many more millions were shipped because they were no longer needed in NATO-countries nor in the former Warsaw Pact area: wildlife paid and still pays the Peace Dividend. For your information, in the international arms trade, AK-47s are merely classified as 'small firearms' [41].

Violence is easy, killing wildlife is easy, and protection personnel feel the threat of running into armed conflicts with poachers. In many places, there is no law and order, and in many places the legitimacy of Government is at stake. This is not typical for Africa: Did you know that India's forests and wild places are for about $30 \%$ controlled by the Naxalites - some sort of Maoist insurgency? Since about 2010 the influence of the Naxalites may be declining because of 'Operation Green Hunt', but anti-poaching personnel is greatly threatened. Few in the Netherlands had heard about the recent Civil War in Nepal, but the stories that local wildlife protection officers can tell you are hair-raising. So are the stories that some of my former PhD students have told me [42]. In other words, where 'Green Violence' occurs, it is wrong, but it can easily be understood: wildlife protectors often feel mortally threatened.

However, that leads to poachers feeling threatened too. So simple 'policing' morphs into 'Green Militarization' which then may easily escalate on both sides into 'Green Violence'. Even in a peaceful country as the Netherlands, a government minister asked foresters (in Dutch 'boswachters') to don bulletproof vests instead of strengthening the police in the countryside [43]. That would have been a first step towards ‘Green Militarization'. 
Finally, before I turn to Artificial Intelligence, it's important to note that in many countries it is unsafe to be arrested. In numerous parts of the world, one would be raped - perhaps even with the chance to be infected with AIDS - within days, whether one is a woman or a man. And one may linger in a beastly prison for years without seeing a judge [44].

\section{Artificial intelligence against poaching}

And now, what about AI - artificial intelligence? A few years ago, I was asked by the Dutch NWO to consider teaming-up with the Netherlands Forensic Institute to focus on wildlife crime. When it comes to solving crimes, forensic science is crucial. But after a crime has happened. So, for example, if a White rhino has been killed on a property and a person is found dead nearby, forensics may help the authorities to unravel what happened and bring anyone involved in the crime to justice. But, when I was in that meeting on the 26th of March 2014, I experienced an epiphany, as Americans would call it. I realized that my professional calling was not to enact revenge by identifying a criminal, and my vocation was not to get any fellow human being into a prison where she or he could be raped or otherwise harmed. Neither science nor revenge can restore the life of a dead rhino or person. But what if science could prevent the killing?

At that moment, it occurred to me that beyond scientific inquiry, my intelligence and knowledge should be used to investigate ways to prevent the killing of rhinos or elephants. Remember how at the start of this lecture I referred to Martin Luther's interest in moral theology - particularly concerning concepts of 'good' and 'evil'? If you can prevent a crime, you are siding with the 'good' and if a poacher could be apprehended before violating the law and be seized only for trespassing for which one normally does not go to jail, you work for a better world. It would be even worthier if one could devise a system in which rangers would know beforehand where a potential poacher would hide in the bush and use that intelligence to deescalate the spiral of fear and violence. This, I thought, would decrease the chances of 'Green Violence'.

In my group [45], we had moved already towards Artificial Intelligence. With funding from the European Commission, we had been doing cutting edge work on the precision of animal tracking, and we had made some fascinating discoveries using free-ranging cattle as model species. Like many other ecologists, we had played with animal tracking but now we were moving the mathematics into much more exciting directions than previously. Therefore, when I thought on my hoofs about why I did not want to work on forensics, I made a bold move and announced that we 
should work on predicting where and when a wildlife crime was going to take place in the bush. In other words, we had to develop predictive analytics - but of what? The poachers would not be wearing sensors. Moreover, I did not want any sensors placed on rhinos. If we did that, anyone with some radio tracking skills would be able to pinpoint those rhinos and target them for killing. Indeed, the system that I wanted should decrease the risk for rhinos, and not increase it.

In the months before that fateful meeting with NWO and NFI, we were deeply absorbed in work on the interplay between zebra and wildebeest on the one hand, and between them and lions on the other. We discovered that lions are not simple ambush killers, as was published. Rather, we found that lions may stalk for hours and the zebra or wildebeest may evade for hours - not by running but by constantly keeping a safe distance and counteracting the movements of the lions. If one sees it on a computer screen, it reminds one of a war game or indeed of a game of chess. The data show an enormous environmental awareness of these wildebeest or zebra. However, when you are observing them in the field you do not pick it up at all, especially not in the wooded bush where many of these prey and predators operate in southern Africa. Only when you put sensors on the animals, and only when you analyse their movements with advanced mathematical tools, do you realize that these simple large grazers are the outcome of millions of years of evolution that honed their sensors to perfection. We call their sensors 'ears', 'noses' and 'eyes'. They have knowledge of their terrain, they know where they can run and where they cannot; they know where a fence is that a lion could use as stopping device during a chase. They have a brain to process all these incoming data perhaps better than any integrated sensor ever can do. And then the penny dropped: I proposed to use large herbivores as biosensors to detect poachers, and through advanced mathematical analytics deduct from their movement patterns where a poacher would hide or walk.

Ladies and Gentlemen: Suddenly I felt young and bright again. Here was a brandnew challenge to be tackled. I had been trained as a behavioural ecologist, and after decades of research and collaboration, I think that I am better versed in large mammal ecology than most: I have had the privilege and pleasure of receiving a profound education in vegetation ecology, and I've done considerable work on remote sensing. I have very good contacts in Africa, and I have been working a lot with corporate industry. Most significantly, I have in my brain the integrated knowledge of more than one hundred $\mathrm{PhD}$ students. I feel beyond fortunate that NWO funded this exciting idea, and that I was able to forge cooperative agreements with IBM (the computer giant), enChoice (a data company), MTN (a telecommunication giant), and Welgevonden Game Reserve, which in my estimation is Africa's best-managed game reserve and is incomparable to anything I have seen 
in Europa, Australia or Asia. Moreover, I found the MF-Foundation willing to pay large sums to catch, transport and release the many sentinel animals that we needed. Impala, wildebeest, eland antelope and zebra are roaming the veld where we have done many intrusion experiments to mimic poaching. A LoRa-network had to be designed and built, and data transmission through data banks in the Middle East, Canada and Europe had to flow. Data gushed richly to Wageningen where through the very able hands of Henjo de Knegt and Jasper Eikelboom the data transformed into the Artificial Intelligence product that we need.

At the same time, in Welgevonden we built armoured data warehousing, in which we set up a Joint Operation Command centre. We forged cooperation with the army and police on intelligence, constructed booms on roads with number plate recognition linked-up to stolen car register systems, and we finished a car tracking system inside the Reserve. Our predictive analytics of the sentinel large mammals and sensor data will be integrated into this Joint Operation Command centre. Thus, Ladies and Gentlemen, we hope to reduce the risk for the protected species that are really on the brink of extinction. Rhino poaching has killed perhaps already $90 \%$ of all African rhinos in the last 10 years. In the same period, in Welgevonden we have lost only one rhino through poaching, not a single ranger, and also not a single poacher or trespasser lost his or her life. Of course, we want to roll this out to more protected areas. We need even more money, and I will be forever begging for money as I have done to finance many scores of PhD students.

I will continue working in this compelling integrated field of nature preservation and artificial intelligence. We urgently need to develop a particular type of drone, which will look like an eagle and use flapping flight to inspect the outcome of our predictive algorithms. When our algorithms deduce from the complex behaviour of sentinel animals where likely a poacher is hiding, I want to be able to have that verified before rangers have to risk their lives. We need sensors for another 3000 animals and we need more LoRa-towers. And we need more very able brains.

My talk is a public lecture with students in attendance, and I specifically turn to you. As I see it, the lives of rhinos are nearly sacrosanct, as are the lives of rangers - and poachers. When discussing drones, I often heard the enthusiastic reaction from you and fellow students: 'Ah, then we can shoot poachers from the air!' My answer is: Please stop that way of thinking. Poachers have rights - if they have done something illegal, they should be brought to court. 'Green Violence' is just as evil as any other form if violence. Most poachers are people who were trained in armed struggle and know how to make a living out of shooting but nothing else, or they are unemployed youth who see no future for themselves and want to buy bling bling to impress girls. 
There is no indication that they operate in 'gangs' with all the gang psychopathy of hardened criminals, perhaps there is not even evidence for syndicate leaders who order the killing of particular rhinos.

Our task as students of life is to use our brains, skills and knowledge to enhance and protect that life. Within the arena of nature preservation, our charge is to devise approaches that are so advanced and so effective that wildlife will persist on Earth without violence by our species - be they poachers or protectors. It is my conviction that you and I can do that by bringing artificial intelligence and the best of science to the table.

Mijnheer de Rector, I have been a full professor at this University for more than 10,000 days. Before I was appointed some 27 years ago, the then Board of this University expressed as its fear that I would not stick to my academic field, namely 'Nature Conservation in the Tropics'. That Board was correct: I expanded the field much and even set up research outside of the tropics. A next Board tried to provide cover-up, and changed my assignment to 'Nature Conservation in the Tropic and Ecology of Vertebrates'. To make it worse, perhaps, I lead my group [45] to work on remote sensing, hydraulic lift by trees, the mathematics of vegetation patterns, the effect of fire, disease ecology and landscape genetics. Another Board came, and to cover this wide enlargement of my assignment allowed a new name for my Chair, namely 'Resource Ecology'. This was a wise decision, because no-one really knows what it is and what it means. I thus thank you profusely for the trust you gave me to develop a field without the constraints of a name because it gave us the means to truly innovate. By retiring, I hand in my leeropdracht [45].

Mijnheer de Rector, I will end my last public lecture as professor at this University with the time-honoured words:

'Ik heb gezegd' 


\section{References and notes}

Because much in my valedictory may at times sound foreign perhaps, or even alien, but definitely unfamiliar to most here in the West, I substantiated nearly every paragraph of the valedictory in the following notes and references to the literature: these notes are thus an integral part of the narrative. One could spend a lifetime in getting to understand realities that most of us are not or hardly aware of, and, indeed, I spent half a lifetime on it already.

[1] The Ninety-Five Theses (or propositions) were meant for a debate amongst scholars. Wageningen University still honours this ancient tradition during the public defence of a doctoral dissertation. For more on Luther see, for instance: Marshall, P. (2017). 1517: Martin Luther and the Invention of the Reformation. Oxford University Press, Oxford, England. Martin Luther not only wanted to see the church reformed, he also held the opinion that the universities had to reform: Kittelson, J.M. (1984). Luther's impact on the universities-and the reverse. Concordia Theological Quarterly 48: 23 - 38.

[2] Moral theology is, like in Luther's days, an important field of research, and perhaps even contemplation in modern society. For a quick introduction, see: Laing, J. (2012). Moral Theology. In: The Encyclopedia of Christian Civilization. Blackwell's, London, England. Deeper delving is: Mahoney, J. (1987). The Making of Moral Theology: A study of the Roman Catholic tradition. Oxford University Press, Oxford, England. Hot debates that affect many of us are, for instance, on marriage (e.g., Cahill, L.S. [2003]. Notes on moral theology marriage: developments in Catholic theology and ethics. Theological Studies 64: 78 - 105), abortion (e.g., Castuera, I. [2017]. A social history of Christian thought on abortion: ambiguity vs. certainty in moral debate. American Journal of Economics and Sociology 76: 121 - 227) or healthcare (Padela, A.I. [2017]. Social responsibility and the state's duty to provide healthcare: an Islamic Ethico-Legal Perspective. Developing world bioethics 17: 205 - 214). For those who want to delve further, try: Peschke, K.H. (2012). Christian Ethics, Volume 2: Moral Theology in Light of Vatican II; Volume II Special Moral Theology. Wipf and Stock Publishers., Eugene, Oregon. The content of the book by Gardella, P. (2016) (Updated Edition). Innocent Ecstasy: How Christianity Gave America an Ethic of Sexual Pleasure. Oxford University Press, New York, New York shows how wide the issue of 'moral theology' is.

[3] The Carnation Revolution of 1974 in Portugal is well described and learned books have been published on it; see for instance: Maxwell, K. (1997). The Making of Portuguese Democracy. Cambridge University Press, Cambridge, England or Pinto, P.R. (2015). Lisbon Rising: urban social movements in the Portuguese revolution, 1974-75. Manchester University Press, Manchester, England. Later, when I was doctoral student at Cambridge (Darwin College) and my good friend Ron Ydenberg was the same at Oxford (Wolfson College), we learned that the Oxbridge Colleges had purchased many barrels of very good port wine at rock bottom prices, keeping the dons well provided for decades. The Dutch flower exporters earned much from exporting 
carnations to the revolutionaries. We students had our sometimes-grim interactions with police and secret police with shepherd dogs. We conducted 'biological warfare' by catching stray cats, hiding them under our coats, and releasing them when the police attacked with dogs. These three simple threads of history (port wine, flower export and releasing cats) do not help solving any ethical or moral debate, I fear.

[4] Major land abonnement has happened several times in Western Europe. A very severe one was during the 5th and 6th century C.E. when perhaps the present Netherland became devoid of farmers and the Roman administration and armies abandoned much of the Netherlands but also France and Spain. For the Netherlands consult Van Es, W.A. \& W.A.M. Hessing (eds.) (1994). Romeinen, Friezen en Franken in het Hart van Nederland: van Traiectum tot Dorestad 50 v. Chr. - 950 na Chr. Rijksdienst voor het Oudheidkundig Bodemonderzoek, Amersfoort, the Netherlands. The letters of Sidonius Appolinarus (430 - 489 C.E.) sketch an intriguing landscape of land abandonment: Sidonius (1936) Poems. Letters; Book 1 - 2. Loeb Classical Library Vol. 296. Loeb, William Heinemann, London, England; Sidonius (1965). Letters: Book 3 - 9. Loeb Classical Library Vol. 420. Loeb, William Heinemann, London, England. For his time and place see for instance Drinkwater, J. \& H. Elton (eds.) (1992). Fifth-century Gaul: a crisis of identity? Cambridge University Press, Cambridge, England. Mediaeval 'Wüstungen' (as they are known in German; 'lost' or 'deserted' villages) widely occur, partly as result of the Black Death, see, for instance, Rösener, W. (2010). Agrarwirtschaft, Agrarverfassung und ländliche Gesellschaft im Mittelalter. Enzyklopedie Deutscher Geschichte Vol. 13. Oldenbourg Verlag, München, Germany; Caspari, V. (2019). Die Wirtschaft im Mittelalter. In Ökonomik und Wirtschaft, pp. 15 - 32. Springer Gabler, Berlin, Germany; Simms, A. (1976). Deserted Medieval villages and fields in Germany: a survey of the literature with a select bibliography. Journal of Historical Geography 2-3: 223 - 238; Beek, R.V., B. Groenewoudt \& L. Keunen (2014). Establishing the dates of farm sites (AD 800-present) in Salland (the Netherlands): an interdisciplinary approach. Journal of Field Archaeology 39: 51 - 66 .

[5] President Julius Nyerere, the first president of Tanganyika and later Zanzibar (which was united under the name Tanzania) created an economic disaster as is well-published, e.g., Hyden, G. \& B. Karlstrom (1993). Structural adjustment as a policy process: the case of Tanzania. World Development 21: 1395 - 1404; Pratt, C. (1999). Julius Nyerere: reflections on the legacy of his socialism. Canadian Journal of African Studies / Revue Canadienne Des Études Africaines 33: 137 152; Ibhawoh, B. \& J.I. Dibua (2003). Deconstructing Ujamaa: The legacy of Julius Nyerere in the quest for social and economic development in Africa. African Journal of Political Science 8: 59 - 83. He was a nice man though, and because he had been teacher everyone in Tanzania talked about him with respect as ' $m$ walimu' (the teacher). My father was very well-acquainted with him as was my 'Oom' Ernst van Eeghen. The latter's wife (Erica Van Eeghen-Van Panhuys) created a suit for Nyerere when he refused to go in western dress to meet Queen Juliana at the Palace for a state banquet. The dress created by 'Tante Erica' later became the national official attire (later 
taken further by president Nelson Mandela of South Africa). An important reason for selecting this batik-type textile was that the Dutch textile industry had lost preferential access to the Indonesian market after its konfrontasi politik.

[6] The idea of a Pax Britannica was based on the Pax Romana. It has been defined as QUOTE 'British peace - used for the period of relative tranquillity from circa 1815 to 1914 in the regions to which Britain's power extended' END QUOTE (Webster's Dictionary). Anyone who is acquainted with the facts from the Boer War (e.g., Pakenham, T. [1991]. The Boer War. Time Warner Books UK, London, England), or the horrors of the Great Mutiny (see, e.g., Dalrymple, W. [2007]. The Last Mughal: the fall of a dynasty, Deli, 1857. Penguin, London, England), or the serious killing during the Zulu War (e.g., Morris, D.R. [1989]. The Washing of the Spears: the rise and fall of the Zulu Nation. Pimlico, London, England) will baulk when s/he reads 'tranquillity'. Yet, if one models this peace on that of the Romans, and one understands that Julius Caesar's wealth was built on selling slaves from France, Belgium, Portugal and Spain, then the British Peace was indeed comparable to the Pax Romana (see Goldsworthy, A. [2016]. Pax Romana: war, peace and conquest in the Roman world. Weidenfeld \& Nicholson, London, England; Goldsworthy, A. [2013]. Caesar: The life of a colossus. Hachette, London, England, in which the estimate is put forward that Julius Caesar had been instrumental in having hundreds of thousands of people killed, and hundreds of thousands sold into slavery). More on slavery in ancient Rome can be found in Bradley, K. (1994). Slavery and Society at Rome. Cambridge University Press,

Cambridge, England; or in Bradley, K.R. (1987). On the Roman slave supply and slavebreeding. Slavery and Abolition 8: 42 - 64. The beautiful stories and poetry of the period are of little help to understand the savagery of colonial occupation forces (compare, for instance, the poetry of Lucan with that of Kippling: Braund, S.H. (1992). Lucan: Civil War. Clarendon Press, London, England and Kipling, R. (1940). Rudyard Kipling's Verse: Definitive Edition. Doubleday, London, England). Both glorified 'empire'.

[7] Still the best introduction on the spread of sleeping sickness in people, trypanosomiasis in livestock as a result of bush encroachment in the first half of the 20th C can be found in Ford, J. (1971). The Role of the Trypanosomiases in African Ecology: a study of the tsetse fly problem. Clarendon Press, Oxford. Monumental. See also Worboys, M. (1994). The comparative history of sleeping sickness in East and Central Africa, 1900-1914. History of Science 32: 89 - 102, or Muriuki, G.W., T.J. Njoka, R.S. Reid \& D.M. Nyariki (2005). Tsetse control and land-use change in Lambwe valley, south-western Kenya. Agriculture, ecosystems $\mathcal{E}$ environment 106: 99 - 107. There are scores of papers on this issue.

[8] Rinderpest was an alien cattle disease brought to Africa from India by a British invasion army aimed at putting down the Rebellion of the Mahdi after 'Gordon of Khartoum' had been beheaded. This invasion was led by Horatio Kitchener in 1896 (the man who later devised the concentration camps in which many a Boer came to a bitter end). The flash in the pan that 
started the Mutiny in India (see note \#6) was that the newly invented rifles needed well-greased cartridges which had to be ripped open with the teeth when the Indian sepoys had to shoot: Hindu sepoys were informed by their British officers that this grease was made from hogs and not from cows while Muslim sepoys were told by their British officers the exact opposite. So, both groups of soldiers felt religiously soiled (and then mutinied). The British did not want to make this error again, and to unambiguously signal this they imported cattle, from India, to show to their Muslim troops that this fat was not from hogs. Yet, these cattle were carrying rinderpest. The disease spread like wildfire, and already in 1889 reached Masailand. In its wake, about $90 \%$ of all livestock had found their death (and an equal proportion of wild ruminants). I could exactly date this first occurrence with aid of the Observatory in Utrecht because oral tradition remembered its co-occurrence with a particular lunar eclipse. In Tanzania and Kenya the arrival of the disease is still visible in the landscape: Prins, H.H.T \& H.P. van der Jeugd (1993). Herbivore population crashes and woodland structure in East Africa. Journal of Ecology 81: 305 - 314; Prins, H.H.T. (1996). Ecology and Behaviour of the African Buffalo: social inequality and decision making. Chapman \& Hall, London, England, pp. 122 f.f.

[9] Only when an enormous vaccination programme by FAO, in which hundreds of thousands of cattle were vaccinated, had eradicated the rinderpest, the now famous wildebeest population could bounce back. In the Serengeti, there were about 90,000 head of wildebeest in the 1950s but in the 1980s (after the eradication of the alien disease) the population rebounded to about 1.5 million. See: Sinclair, A.R.E. (1979). The eruption of the ruminants. In: A.R.E. Sinclair \& M. Norton-Griffiths (eds.). Serengeti: dynamics of an ecosystem, pp. 83 - 103. Chicago University Press, Chicago, Illinois, and also Prins, H.H.T. \& F.J. Weyerhaeuser (1987). Epidemics in populations of wild ruminants: anthrax and impala, rinderpest and buffalo in Lake Manyara National Park, Tanzania. Oikos 49: 28 - 38. Rinderpest was officially declared eradicated in 2007; the actions that were taken are well described in Mariner, J. C., J.A. House, C.A. Mebus, A.E. Sollod, D. Chibeu, B.A. Jones ... \& G.G. van't Klooster (2012). Rinderpest eradication: appropriate technology and social innovations. Science 337: 1309 - 1312, and even better in Roeder, P., J. Mariner \& R. Kock (2013). Rinderpest: the veterinary perspective on eradication. Philosophical Transactions of the Royal Society B: Biological Sciences 368: 20120139. At the basis of the eradication lies the work of Plowright, W. (1984). The duration of immunity in cattle following inoculation of rinderpest cell culture vaccine. Epidemiology $\mathcal{E}$ Infection 92: 285-296 and much credit for the eradication but also for the fabulous recovery of the Serengeti Ecosystem should go to Walter Plowright whose input was rightly mentioned by Robertshaw, D. (2010). Credit to Plowright for rinderpest eradication. Science 330: 1477 - 1477. Plowright did more for nature conservation than David Attenborough! Intriguingly, the former animal trader got a building named after him (at the University of Cambridge, England) while the microbiologist did not.

[10] A very good source is Kjekshus, H. (1977). Ecology Control and Economic Development in East African History. Ohio University Press, Athens, Ohio. This book has profoundly changed my 
thinking about ecology, and like Ford's book (referred to in note \#7), made me painfully aware that 'every ecologist should be an historian'. Ultimately this resulted in a book I edited with my good friend Iain Gordon in which we explored the enormous importance of contingency in ecological processes: Prins, H.H.T. \& I.J. Gordon (eds.) (2014). Invasion Biology and Ecological Theory: insights from a continent in transformation. Cambridge University Press, Cambridge, England.

[11] Surrounding Bardiya National Park in Western Nepal, there is a buffer zone with nowadays tens of thousands local farmers where 30 years only a few hundred lived. During the Nepal Civil War (1996 - 2006), the local Asian elephants fled to neighbouring India but returned after the war. They found the natural grasslands in the floodplain of the Karnali River nearly completely converted into irrigated agriculture, so when they desired to visit their homelands, they found tens of thousands of people instead of natural grass. Hence, they started feeding on rice which people do not approve of, and accidents (sometimes fatal) take place. Together with friends of the Himalayan Tiger Foundation, we designed a fence, described in Liefting, Y., J.F. de Jong \& H.H.T. Prins (2018). A new type of elephant fence: permeable for people and game but not for elephant. Gajah 49: 11 - 19. An important driver for us was seeing a grandfather with the lifeless body of his granddaughter in his arms. She had fallen out of her bed on the 2nd floor of their dwelling when a bull elephant had ripped out the complete wall, and stepped on the girl. The incident with the woman who had cried her grief out to me was when I travelled with one of my PhD students (Mikhael Grishchenko) over the great Yenisei River in Siberia: the brown bear had first mauled her neighbour and then the neighbour's daughter. Both died. The closest hospital is perhaps three days by boat. If one reads a title like: Grishchenko, M., H.H.T. Prins, R.C. Ydenberg, M.E. Schaepman, W.F. de Boer \& H.J. de Knegt (2019). Land use change and the migration geography of Greater White-fronted geese in European Russia. Ecosphere 10(8), p.e02754, one does not suspect these types of incident. I got the first inkling of the meaning of her sobbing when I picked up the word 'medveya' again and again, which I happened to understand because of the ТРИ МЕДВЕДЯ ('Tri Medveya') beer brand from the Ivan Taranov brewery based in Novotroitsk, which we drank in Siberia.

[12] To better understand this, and the role of former East Germany (the DDR), see, for instance: Lal, P., (2015). African Socialism in Postcolonial Tanzania. Cambridge University Press, Cambridge, England. Chinese influence was also strong: Altorfer-Ong, A.N. (2014). Old comrades and new brothers: a historical re-examination of the Sino-Zanzibari and Sino-Tanzanian bilateral relationships in the 1960s. Doctoral dissertation, The London School of Economics and Political Science; Tripp, A.M. (1989). Defending the Right to Subsist: the state vs. the urban informal economy in Tanzania. World Institute for Development Economics Research of the United Nations University, Tokyo, Japan. One may dislike the Heritage Foundation, but Ayittey, G.B. (1990). The End of African Socialism? Heritage Foundation, Washington D.C., is worth reading, but Shivji, I.G. (1990). State Coercion and Freedom in Tanzania. Human \& People's Rights Monograph Series 8, Institute of 
Southern African Studies, National University of Lesotho tells the story perhaps best. A story of massive coercion, suppression, poverty and hunger. Even the cinema was under tight control: Brennan, J.R. (2005). Democratizing cinema and censorship in Tanzania, 1920-1980. The International Journal of African Historical Studies 38: 481 - 511.

[13] Ellis, S. \& T. Sechaba, T. (1992). Comrades against apartheid: the ANC E the South African Communist Party in exile. Indiana University Press, Bloomington, Indiana. Roadblocks had been set up to control transport of food and goods from one province to another. My main supply had to come from Arusha, at that time nearly a full days' drive from my camp, but that was in a different province. I had been taught by a Gurkha sergeant in Nepal how to crash with a car through a police road block when I was a hippie there; now that proved to be useful knowledge. For many unsuccessful ways of doing this, watch https://www.youtube.com/ watch? $\mathrm{v}=\mathrm{wXTICOj-tmU}$ and many other films, but to understand the issues better you could consult https://www.artofmanliness.com/articles/how-to-ram-through-a-vehicular-roadblock/ . It is dangerous, no fun, and often illegal. I thus do not recommend doing it.

[14] The Uganda War (1979-1980) took place after Idi Amin, the dictator of Uganda, had killed between 100,000 and 300,000 Ugandans, often atrociously. Against international doctrine enshrined in the rules of the United Nations, president Julius Nyerere decided to intervene. The war lasted briefly and the Tanzanian Army first defeated the Libyan forces and then the Nubians from NE Uganda (the home area of Amin). The legal justification of the war is well described in Farooq, H. (1980). Realpolitik in International Law: After Tanzanian-Ugandan Conflict Humanitarian Intervention Re-examined. Willamette Law Review 17: 859 - 912. The Tanzanian troops stayed much longer than the war itself. The war crippled the Tanzanian economy even further: Roberts, G. (2014). The Uganda-Tanzania War, the fall of Idi Amin, and the failure of African diplomacy, 1978-1979. Journal of Eastern African Studies 8: 692 - 709. In Uganda, civil war broke out between 1981 and 1986 in which Tanzanian troops still played an important role. For more on this, see: Baker, B. (2007). How civil war altered policing in Sierra Leone and Uganda. Commonwealth E Comparative Politics 45: 367 - 387. For a deeper understanding of the politics and economics of roadblocks: Schouten, P. (2019). Roadblock politics in Central Africa. Environment and Planning D: Society and Space, DOI 0263775819830400.

[15] The problem I was facing with these young men ( a few years younger than I) in my household was, of course, not as bad as trying to reintegrate the thousands of the Ugandan child soldiers at the time for which see Dodge, C.P. \& M. Raundalen (1991). Reaching Children in War: Sudan, Uganda and Mozambique. Sigma Forlag, Bergen, Norway. Not discussing war traumas can be perhaps a good strategy: Tankink, M., (2004). Not talking about traumatic experiences: Harmful or healing? Coping with war memories in southwest Uganda. Intervention: International Journal of Mental Health, Psychosocial Work and Counselling in Areas of Armed Conflict 2: 3 - 17. I solved it by reading stories to them from: Knappert, J. (1970). Myths and Legends of the 
Swahili. Heinemann, Nairobi; see also Knappert, J. (1977). Bantu myths and other tales (Vol. 7). Brill Academic Publishers, Leiden, the Netherlands. I did not allow reminisces of the war to be discussed after sunset, and rifles and guns had to be stored in my bath-hut. My Sukuma head-ranger, Mhoja Burengo, who had been trained as witch-doctor before he joined Tanzania National Parks was a truly wise man with whom it was good to strategize the optimal approach for coping with trauma and maintaining safety amongst us. He spoke at least seven languages, knew tens of recipes for brewing different types of local beer, but also hundreds of plant species and their scientific names, taught me how to follow the tracks of a cobra through the grass and over rocks, how to use a fire bow (a.k.a. bow drill) and elephant dung to make a fire, or how to approach lions, elephants or buffalo on foot. He was my best teacher ever.

[16] We lost a high proportion of the incredible elephant population of Lake Manyara National Park, which had the highest density of elephant anywhere in Africa, at a staggering five per square kilometre: Prins, H.H.T. \& I. Douglas-Hamilton (1990). Stability in a multi-species assemblage of large herbivores in East Africa. Oecologia 83: 392 - 400. When the worst of the poaching was over, many young elephants were likely as traumatized as the young soldiers I referred to in note \#15 as evidenced by their broken social organization: Prins, H.H.T., H.P. van der Jeugd \& J.H. Beekman (1994). Elephant decline in Lake Manyara N.P., Tanzania. Journal of African Ecology 32: 185 - 191. As mentioned, all Black rhino were exterminated, not only in Lake Manyara N.P., but also in the adjacent Tarangire N.P., Arusha N.P. and Serengeti N.P. and the last I could salvage was a morphological description of the sub-species: Prins, H.H.T. (1990). Geographic variation in skulls of the nearly extinct Small black rhinoceros Diceros bicornis michaeli in northern Tanzania. Zeitschrift für Saugetierkunde 55: 260 - 269. One of the highlights in my life was when we identified a number of rhinos of this East African subspecies in South Africa (so outside of their range). They had been exported to that country when there were still many in Tanzania and very few in South Africa, but when conservation worked very well in South Africa, the conservation authorities had decided that, because they were of the 'wrong sub-species' they could be released for trophy hunting. I raised money from the Van Tienhoven Foundation to airlift them to Mkomazi National Park in northern Tanzania, where they belonged. Tony FitzJohn had to build a special runway in the bush for the planes to land.

[17] Much was covered-up and kept sub-rosa and it took years to emerge. A bit of the veil is lifted in Leader-Williams, N., R.D. Baldus \& R.J. Smith (2009). The influence of corruption on the conduct of recreational hunting. In: B. Dickson, J. Hutton \& B. Adams (eds.). Recreational Hunting, Conservation and Rural Livelihoods: Science and Practice, pp. 296 - 316. Blackwell Publishing, Oxford, England. See also: Hurt, R. \& P. Ravn (2000) Hunting and its benefits: an overview of hunting in Africa with special reference to Tanzania. In: H.H.T. Prins, J.G. Grootenhuis \& T.T. Dolan (eds.). Conservation of Wildlife by Sustainable Use, pp. 295 - 313. Kluwer Academic Publishers, Boston, Massachusetts. More can be found in: Maliyamkono, T.L. \& 
M.S.D. Bagachawa (1990). The Second Economy in Tanzania. James Currey, London; United Republic of Tanzania (URT) (1996). Commission Report on the State of Corruption in the Country. PUBD.121996.001 COR. Dar-es -Salaam., Tanzania.

[18] Names are withheld by me.

[19] A good description of the way how fieldwork was done at the time (so, in the days that there was no internet, no laptops, and telephones hardly functioned) can be found in the bundle edited by Monique Burgerhoff-Mulder. As anthropologist she understood that it could be useful perhaps for a next generation of scientists to get a feel of how we did research at the time. The profit of this book went to a relief fund: M. Borgerhoff Mulder \& W. Logsdon (eds.) (1996). I've been gone far too long: field trip fiascos and expedition disasters. RDR Books, Oakland, California. I wrote a chapter for the book too as Prins, H.H.T. (1996). An East African survival course. In ibid pp. $65-76$.

[20] Royal Dutch Shell started prospecting for oil in 1975 and made thousands of kilometres of seismic lines through the Selous Game Reserve in southern Tanzania. 'Seismic lines' are straight swaths of bush that are clear-cut along in which holes are augered in the topsoil; in these holes microphones or dynamite bars are lowered. After detonating the dynamite, the 'echo's' are mapped to get a three-dimensional image of the deep geological structure. The African elephant population was stable till about 1981 at a level of some 80,000 individuals, and so was the Black rhino population at 3000 individuals. Then the poaching started because the access to the Reserve became very easy along these seismic lines: Borner, M. \& E. Severre (1981). Rhino and elephant poaching trends in the Selous Game Reserve: https://pdfs. semanticscholar.org/f0a8/48429145116ef1fbb2544489e6f75799ab11.pdf Hence, this is a good example of the so-named 'resource curse': Shaxson, N. (2007). Oil, corruption and the resource curse. International Affairs 83: 1123 - 1140; read also Kenyon, P. (2018). Dictatorland: the men who stole Africa. Head of Zeus, London, England. I read this book jointly with good friend Joost de Jong while on an expedition over glaciers in the border area of India, Pakistan and China; weight limitation becomes an issue when your horses sink to over their bellies in the snow. The rhino population was exterminated in the Selous, but the elephant population recovered: Siege, L. (2000). From Decline to Recovery: the Elephants of the Selous. Tanzania Wildlife Discussion Paper No. 27, Dar-es-Salaam, Tanzania; Blanc, J.J. (2007). African elephant status report 2007: an update from the African elephant database (No. 33). IUCN, Gland, Switzerland. Another good friend, Paul Loth, and I proposed to Shell to investigate this, and take remedial action. Competing conservationists blocked our proposal where Shell was not unwilling to finance. At present poaching is very severe again.

[21] The Maji-Maji Rebellion (1905 - 1907) was perhaps the largest of the African uprisings against a colonial power. An excellent analysis is given by Giblin, J. \& J. Monson (2010). Maji 
Maji: lifting the fog of war. Brill, Leiden, the Netherlands. In the area, one can still find the remains of the war waged by the brilliant Von Lettov-Vorbeck (nicknamed the 'Löwe von Afrika') against invading British into Deutsch Ost-Afrika (1914 - 1918). The easiest read on this is perhaps Boyd, W. (1982). An Ice-Cream War. Penguin, London, England, but see also Von Lettow-Vorbeck, P.E. (1920) Heia Safari! Deutschlands Kampf in Ostafrika. Hase E Köhler, Leipzig, Germany.

[22] See for instance Kjekshus, referred to in note \#10.

[23] During the colonial era, there were many wildlife eradication programs in place, often at a massive scale and for many years. Many were aimed at the eradication of animal species that were thought to be carriers of diseases, or hosts for tsetse flies. Where we now talk of 'wildlife corridors', then there was talk of creating wildlife-free zones, for example, connecting Lake Tanganyika with Lake Malawi over a distance of $300 \mathrm{~km}$ long and $80 \mathrm{~km}$ wide; see Prins, H.H.T. (1996). Ecology and Behaviour of the African Buffalo: social inequality and decision making. Chapman \& Hall, London, England pp. 126 f.f., and Matthiessen, P. \& B. Douthwaite (1985). The impact of tsetse fly control campaigns on African wildlife. Oryx 19: 202 - 209.

[24] Search the world wide web for ' Ivory War' and you will find hundreds of film fragments, videos, newspaper clippings, etc., on the issue how elephants have been wantonly killed for their ivory to finance rebellions, wars, uprisings, counter rebellion, enrichment, etc. Recent scholarly papers are, for instance, Brennan, A.J. \& J.K. Kalsi (2015). Elephant poaching \& ivory trafficking problems in Sub-Saharan Africa: An application of $\mathrm{O}^{\prime} \mathrm{Hara}^{\prime}$ s principles of political economy. Ecological Economics 120: 312 - 337; Titeca, K. (2018). Understanding the illegal ivory trade and traders: evidence from Uganda. International Affairs 94: 10776 -1099. In my research group, we investigated the current distribution of African elephant across Africa and found disturbing negative statistical effects on their distribution and density of poverty, illiteracy and poor governance: Boer, W.F. de, F. van Langevelde, H.H.T. Prins, P.C. de Ruiter, J. Blanc, M.J.P. Vis, K.J. Gaston \& I. Douglas Hamilton (2013). Understanding spatial differences in African elephant densities and occurrence, a continent-wide analysis. Biological Conservation 159: $468-476$.

[25] See for an exposé on 'Green Violence': Büscher, B. \& M. Ramutsindela (2015). Green violence: Rhino poaching and the war to save Southern Africa's peace parks. African Affairs 115: 1 - 22; cf. Mogomotsi, G.E. \& P.K. Madigele (2017). Botswana's' shoot-to-kill' policy as an anti-poaching strategy. SA Crime Quarterly 60: 51 - 59.

[26] Lunstrum, E. (2014). Green militarization: anti-poaching efforts and the spatial contours of Kruger National Park. Annals of the Association of American Geographers 104: 816 - 832; Massé, F., E. Lunstrum \& D. Holterman (2018). Linking green militarization and critical military studies. 
Critical Military Studies 4: 201 - 221; Büscher, B. \& R. Fletcher (2018). Under pressure: conceptualising political ecologies of green wars. Conservation and Society 16: 105 - 113.

[27] Gribnau, J.L.M. (2008). Soevereiniteit en Legitimiteit: grenzen aan (fiscale) regelgeving. Rede uitgesproken bij het aanvaarden van het ambt van bijzonder hoogleraar 'Kwaliteit van fiscale regelgeving' aan de Universiteit Leiden op dinsdag 16 december 2008.

[28] Most local poachers came out of the Monduli District, to the west of Lake Manyara National Park. The park lies in the Great Rift Valley at an altitude of about $1000 \mathrm{~m}$ above sea level, and has most likely never been cultivated. The area 'above' it, typically some $2000 \mathrm{~m}$ above sea level was densely settled by Mbulu people, a Cushitic-speaking group rather unrelated to the Masai and Barabaig who speak Nilotic languages. The Mbulu have been cultivating here some thousand years, while the Masai are relative newcomers who arrived some six hundred years later. Nyerere's ujamaa-policy (a policy of villagization), mainly financed by Sweden and the Netherlands, had done immeasurable damage to the local farming societies (see notes \#5, \#12 and \#14). This policy forced people that lived widely scattered across the landscape, close to their arable fields and permanent water sources into villages, normally at cross roads where they could easily be controlled and where frequently there was no easy access to water. The land of local (black) farmers, who often had been very successful and started mechanization already in the 1950s, was confiscated normally beyond about two hectares (pers. comm. Shaabani Swalleh). Risk-minimizing strategies of differential crop planting could thus not be carried out any more, women had to walk hours for fetching drinking water instead of getting it on farm, and the same applied to collecting fire wood. Poverty, failed harvests, increased risk proneness to the normal climate variability, etc., were the result. But one can find publications that are positive about this 'Marxist experiment' too, see, e.g., Hydén, G. (1980). Beyond Ujamaa in Tanzania: underdevelopment and an uncaptured peasantry. University of California Press, Berkeley, California even though the problems were already becoming clear in the early 1970s: Barker, J.S. (1974). ' Ujamaa' in Cash-Crop Areas of Tanzania: Some Problems and Reflections. Journal of African Studies 1: 441 - 463. At the end of 1970s, it was claimed that Tanzania's entire rural population of 14 million had moved into 8000 villages (which was not true yet because one still saw shattered huts across some landscapes, but nevertheless there was this relentless pressure on people to move into villages). One should realize, though, that under British colonial rule (officially in name of the League of Nations/United Nations), a large proportion of the rural population was basically in servitude for the production of export crops. During the ujamaa, lack of production was regularly blamed on farmers not understanding the need for higher production; see more on this in De Vries, J. (1978). Agricultural extension and development-Ujamaa villages and the problems of institutional change. Community Development Journal 13: 11 - 19. I do not think that there were ever questions asked in the Dutch (or Swedish) parliament about the totally undesired side effects of development aid in Tanzania but I could be wrong, of course. 
[29] Under Tanzanian law, people had the right to be heard by a magistrate at the court in the same district as where they lived or were the crime took place, but Tanzania National Parks could bring a case against a poacher anywhere. Because some local wardens understood the local relations well, local 'small poachers' were brought to court locally, but 'big fish' were ideally prosecuted at a court where they had no local links to influence the case. In many Anglophone countries in Africa, this release on bail is prevalent and many courts demand a bail that is so low as to be of no deterrence.

[30] Typically, a ranger carried an outdated Mauser rifle. It was a pre-WWII model, yet, if well-maintained, lethal of course. It was basically the same type as the Mauser 1893/95 Boer model. Rangers were typically issued two bullets only, and if they had shot them, they had to account for the 'missing bullets' before they got new ones. When off-duty in the nearby village, the personal riffles were stored in the armoury.

[31] I do not think this would now be possible anymore. I asked His Royal Highness Prince Bernhard to help me outfitting some 600 men. After just two telephone calls, he brought me in contact with a major in charge of mobilization goods kept at the military depot at the Hembrugterrein north of Amsterdam, and together with that major, I selected T-shirts, khaki over shirts, coats, caps, backpacks, field boots, socks, blankets and mosquito nets. When I looked at the underpants, I informed the major that the Army-type would be unacceptable because of its poor fit and baggy looks. He full-heartedly agreed and said that the Navy had much better: so, we set of for Den Helder's navy base, where we received 1800 well-fitting underpants. When I reported back to HRH at Soestdijk Palace, he suddenly said that it would not be received well, if found out, that through Dutch army support several hundred men in the African bush would walk about with Dutch army marks and emblems. So, after a very brief interaction with the Dutch Minister of Defence, Dutch conscripts were set to work to remove all labels, marks and emblems and to replace these with the WWF Panda logo's. KLM transported tons of material for the Tanzanian rangers to Tanzania for free, where I was instructed by the Prince to ensure fair distribution without theft. I ask myself how I found enough time to do my research. The Prince was always incredible supportive and easy to approach for matters concerning nature conservation.

[32] Annual Reports SANParks, Pretoria, South Africa.

[33] In Indonesia, many fishermen use either poison or explosives, especially over coral reefs where handling nets is difficult. Often, fish that was (and is) poisoned is not sold in the own community but in a neighbouring one. If the poison is cyanide, then, strangely enough, there is not much reason for not eating it (e.g., https://www.scientificamerican.com/article/cyanidefishing/ ) but agricultural pesticides are used frequently too which can make the fish dangerous to eat. When I worked for DHV on a World Bank contract in Indonesia, this was a daily 
occurring news feature, and people were regularly killed by ingesting poison in this way. Both cyanide and pesticides are bad for the coral reef. For a good review see Stanley, J. \& G. Preetha (2016). Pesticide toxicity to fishes: exposure, toxicity and risk assessment methodologies. In: Stanley, J. \& G. Preetha (eds.). Pesticide Toxicity to Non-target Organisms: exposure, toxicity and risk assessment methodologies, pp. 411-497. Springer, Dordrecht, the Netherlands. Perhaps even wore, is the use of explosives: it stuns all fish but it physically damages the reef too. See for a review Chan, A. \& P.A. Hodgson (2017). A systematic analysis of blast fishing in South-East Asia and possible solutions. In 2017 IEEE Underwater Technology (UT), pp. 1 - 6. IEEE, Kaohsiung, Taiwan. Normally, the fish stays perfectly edible although often the meat texture does not have the right 'mouth feel' anymore. I investigated where the explosives came from: many dynamite bars were so-called 'blinds' that failed to explode in seismic operations for oil and gas exploration (see note \#20). About $3 \%$ of the dynamite did not explode and was, of course, written off by the oil companies for safety reasons but then found a second life in the illicit reef blasting industry. When I confronted Royal Dutch Shell with this information at their headquarters in The Hague, their top brass reacted shocked and responded instantaneously by closing gaps in their procedures for accounting of failed explosives; this was then also communicated to other industries. Their decision-making procedures were incomparable (good) to anything I have experienced at universities.

[34] Fletcher, R. (2018). License to kill: Contesting the legitimacy of green violence. Conservation and Society 16: $147-156$.

[35] There is a tendency to use specific terminology about wildlife crime in which terms like 'gang' and 'organized crime' are used. This terminology may lead to equating poaching with better-understood violent urban crime from which it is known that there may be lack of rationality in individual criminal decision-making (Dhami, M.K. \& D.R. Mandel [2012]. Crime as risk taking. Psychology, Crime \& Law 18: 389 - 403; Van Gelder, J.L. [2013]. Beyond rational choice: The hot/cool perspective of criminal decision making. Psychology, Crime \& Law 19: 745 763) and that urban gangs behave even less rational: Papachristos, A.V. (2009). Murder by structure: Dominance relations and the social structure of gang homicide. American Journal of Sociology 115: 74 - 128. These types of criminals may even actively aim for killing law enforcement officers to avoid either retaliation or criminal prosecution, c.f.., Felson, R.B. and S.F. Messner (1996). To kill or not to kill? Lethal outcomes in injurious attacks. Criminology 34: 519 - 545. In such situations, the only strategy left is shoot on sight as reasoned in Messer, K.D. (2010). Protecting endangered species: When are shoot-on-sight policies the only viable option to stop poaching? Ecological Economics 69: 2334 - 2340. At present rhino and elephant are rarely poached with nets, poison or snares anymore but with guns, modern-day poachers are armed with guns (usually AK47 assault rifles, but also heavy calibre weapons, for example, .375 and .458 rifles) which have proven to be more dangerous in a conflict than other types of weaponry by, e.g., Wells, W. \& J. Horney (2002). Weapon effects and individual intent to do harm: 
Influences on the escalation of violence. Criminology 40: 265 - 296, but there is no evidence that poachers even have a higher intention to do harm. Typically, poachers in southern Africa are (1) uneducated unemployed young people from local communities, (2) former military personnel, police officials or game scouts, all of whom would have had specialized training to develop tracking or shooting skills, and (3) former REMANO, FRELIMO and Community Militias from Mozambique; vide Montesh, M. (2012). Rhino Poaching: a new form of organised crime. Report, College of Law, School of Criminal Justice Department of Police Practice, South Africa; Rusell, A. (2015). Rhino poaching: inside the brutal trade. Financial Times 2 October 2015 https://www.ft.com/content/f71d53ea-67b3-11e5-97d0-1456a776a4f5; Charlton, R.W. (2017). Death and Destruction: insight into the rhino poaching epidemic in South Africa. MSc thesis, Department of Criminal Justice Sciences, Illinois Sate U. https://ir.library.illinoisstate.edu/cgi/ viewcontent.cgi?article $=1661 \&$ context=etd ; Nuwer, R. (2018). How to stop poaching and protect endangered species? Forget the 'Kingpins'. New York Times, 24 sep 2018. https://www. nytimes.com/2018/09/24/science/poaching-conservation-rhinos-elephants.html. Typically, poachers foreign to an area rely on informants and guides from the local community for being guided towards their targets. From this I (and intelligence officers I consulted) conclude that decisions to enter a protected area with the intent to kill or harvest protected wildlife therein are mainly governed by rationality: increasing the chance of their detection by (armed) conservation officers then has a deterring effect. More important information in: Gaustadsæther, I.W. (2016). A Critical Analysis of the Relationship between the State and Wildlife Crime. Case: rhino poaching in South Africa. Doctoral dissertation, Stellenbosch University, Stellenbosch.

[36] I travelled there with two current PhD students, namely, Lekishon Kenana and Richard Chepkwony, and a former PhD student Yussuf Wato; they come from a very good crop of PhD students that we have had the pleasure recruiting through long-standing cooperation with the Kenya Wildlife Service. We will submit shortly our paper 'Is the collapse of large mammal populations in Sibiloi National Park and the Chalbi Desert (Kenya) caused by local people or climate change?' Kenya is rich in ethnic identities often with the misnomer 'tribes' (like Europe was) and it is true pleasure to discuss, preferably over a camp fire, one's known and unknown cultural backgrounds and assumptions. Indeed, a different image is incurred when I write 'there were four tribesmen sitting around the campfire, a Kalenjin, a Maasai, a Groninger and a Gabbra' or 'four academics from different corners of the earth were reclining around a fire'. The result is the same, and out of this another paper emerges, on snoring and its evolutionary advantages.

[37] See, for instance, Eaton, D. (2010). The rise of the 'traider': the commercialization of raiding in Karamoja. Nomadic Peoples 14: 106 - 122. More in note \#40.

[38] A main bone of contention between the Kenyan Armed Forces and al-Shabaab (the rebel 
'youth movement' of Somalia) is the control over the harbour of Kismayo, from which illegal export of charcoal takes place to the Middle East and perhaps beyond: Anderson, D. M. \& J. McKnight (2014). Kenya at war: Al-Shabaab and its enemies in Eastern Africa. African Affairs 114: 1 - 27. But apart from that, al-Shabaab is good at fundraising and other forms of taxation: see Keatinge, T. (2014). The Role of Finance in Defeating Al-Shabaab. Royal United Services Institute for Defence and Security Studies RUSI, London, England. When one claims that 'insurgent groups can benefit from the availability of 'lootable' and 'unlootable' resources such as diamonds, narcotics, oil and gas in territory they control' [ibid], then it becomes quickly clear that the difference with big oil, pharmaceutical companies, and the gold mining industry is minute: indeed, what gave Standard Oil of New Jersey a.k.a. Esso a.k.a. Exxon the right to extract revenues from Groningen Gas through NAM and GasUnie? Cross-check \#20 and especially Kenyon, P. (2018) referred there; c.f., Yates, D. (2006). The scramble for African oil. South African journal of International Affairs 13: 1-31; Williams, R. E. (2011). From Malabo to Malibu: addressing corruption and human rights abuse in an African petrostate. Human Rights Quarterly 33: 620 - 648; Coll, S. (2012). Private Empire: ExxonMobil and American power. Penguin., London, England. If we phrase our analysis in the most clinical terms like 'state and non-state actors with global and regional actors' (dixit Akuey, A.A.D. [2018]. South Sudan and the emerging security implications for East Africa. Universal Journal of Educational Research 6: 218 - 225) then the differences blur into nothingness. More details, for instance, in Walker, C. (2014). Somalia's security is tied to its natural resources: al-Shabaab's hold on conflict charcoal raises alarms. Africa Conflict Monthly Monitor Jan 2014: 41 - 48; Olsen, G.R. (2018). The October 2011 Kenyan invasion of Somalia: fighting al-Shabaab or defending institutional interests? Journal of Contemporary African Studies 36: 39 - 53; Levy, I. \& A. Yusuf (2019): How do terrorist organizations make money? Terrorist funding and innovation in the case of al-Shabaab. Studies in Conflict \& Terrorism, DOI: 10.1080/1057610X.2019.1628622 See also: Felbab-Brown, V. (2018). Wildlife and drug trafficking, terrorism, and human security. PRISM : 124 - 137. My friend Floris Deodatus recently informed me that charcoal from Central African Republic is even exported to the Middle East. Both the Chinese 'Belt and Road Initiative' and the Turkish new interest in the area may create new conducts of trade, whether termed by some 'legal' or 'illegal'.

[39] There is much one does not want to read. Nevertheless, consult, for instance: Whitman, R. \& S. Wolff, (eds.). (2012). The European Union as a Global Conflict Manager. Routledge, London; Nováky, N. (2018). European Union Military Operations. Routledge, London; Akonor, K. (2018). Accountability of Peacekeepers in Peacekeeping Missions. In: Karbo T. \& K. Virk (eds.) The Palgrave Handbook of Peacebuilding in Africa, pp. 235 - 246. Palgrave Macmillan, Cham; Raineri, L. \& F. Strazzari (2019). (B)ordering Hybrid Security? EU Stabilisation Practices in the Sahara-Sahel Region. Ethnopolitics 18: 544 - 559. One should not conflate this with 'business for peace' (e.g., Katsos, J.E. \& Y. AlKafaji (2019). Business in war zones: how companies promote peace in Iraq. Journal of Business Ethics 155: 41-56). See some ideas about financing of piracy: 
Siebels, D. (2020). Maritime Security in East and West Africa; a tale of two regions. Palgrave Pivot, Cham; Pichon, E. \& M. Pietsch (2019). Piracy and Armed Robbery off the Coast of Africa: EU and global impact. European Parliamentary Research Service, Brussels; c.f. Bateman, S. (2019). Sea Piracy: some inconvenient truths. https://www.peacepalacelibrary.nl/ebooks/files/UNIDIR_pdfart2960.pdf and consult many stories in, e.g., the Financial Times.

[40] For guns around the Ilemi Triangle (i.e., the internationally undefined area between South Sudan, Kenya and Ethiopia) see: Butler, C. K. \& S. Gates (2012). African range wars: climate, conflict, and property rights. Journal of Peace Research 49: 23 - 34; Collins, R.O. (2004). The Ilemi triangle. Annales d'Éthiopie 20: 5 - 12; Mburu, N. (2003). Delimitation of the elastic Ilemi Triangle: pastoral conflicts and official indifference in the Horn of Africa. African Studies Quarterly 7: 15 - 37; Detges, A. (2014). Close-up on renewable resources and armed conflict: the spatial logic of pastoralist violence in northern Kenya. Political Geography 42: 57 - 65.

[41] For the effect of foreign activities and the proliferation of guns and other 'small' fire weapons you can consult: Chelule, E. (2014). Proliferation of small arms and light weapons: challenge to development, peace and security in Africa. IOSR Journal of Humanities and Social Science 19: 80 - 86; Waqo, H.D. (2003). Peacebuilding and Small Arms: Experiences from Northern Kenya. In: workshop 'UN Biennial Conference of States on Small Arms,' New York, New York; Schmidt, E. (2013). Foreign Intervention in Africa: from the cold war to the war on terror. Cambridge University Press, New York, New York; Abdullah, I. (2016). The state of the proliferation of small arms and light weapons in Sub-Saharan Africa: regional, state and local causes. International Journal of Business $\mathcal{E}$ Law Research 4: 22 - 36. Of course, China has been playing a key role here to beyond the traditional interventions by the USA, the USSR (and presently Russia) as first evidenced already in Tanzania and Ethiopia in the 2nd half of the 20th C; see, for instance: Eisenman, J. (2015). China's post-cold war strategy in Africa: examining Beijing's methods and objectives. In: Eisemann, J., E. Heginbotham \& D. Mitchell (eds). China and the Developing World, pp. 29-57. Routledge, London, England.

[42] In Nepal, we investigated the inequality in resource access and associated risk of elephant raiding: Prins, H.H.T., Y. Liefting \& J.F. de Jong (in press). Human-elephant conflict in Bardiya National Park (Nepal): conservation success affects the poor. Oryx. The Civil War in Nepal lasted from 1996 to 2006: Sharma, K. (2006). The political economy of civil war in Nepal. World Development 34: 1237 - 1253; Miklian, J. (2009). Nepal's Terai: constructing an ethnic conflict. PRIO (International Peace Research Institute) Oslo, Norway. On the Naxalites in India and the Green Hunt: Prasanna, S. A. (2016). Red Belt, Green Hunt, Gray Law: India's Naxalite-Maoist Insurgency and the law of non-international armed conflict. UCLA Law Review 63: 485 - 527; Kujur, R. K. (2017). Naxal movement: resurgence or desperation? In: Armed Conflicts in South Asia 2011, pp. 121 - 146. Routledge India, New Delhi, India; Kumbamu, A. (2019). The Naxalite Movement, the oppressive state, and the revolutionary struggle in India. In: B. Berberoglu 
(ed.), The Palgrave Handbook of Social Movements, Revolution, and Social Transformation, pp. 233 - 247. Palgrave Macmillan, Cham, Switzerland.

[43] The 'veldpolitie' ('countryside police force') was a part of the 'rijkspolitie' ('state police force'; separate from the municipal police at the time) in the Netherlands; the force was scrapped in 1993 to save some money. See for background, for example, Anonymous (1989). Met verdwijnen veldpolitie dreigt natuur/milieuramp. Politie Dier $\mathcal{E}$ Milieu 1989: 67 - 72; Kloosterman, R. (1994). Opheffen van veldpolitie is slecht voor vogels. De Korhaan 28: 61; Corven, T. van \& M. van Laarhoven (1994). Stropers deinzen nergens voor terug. Trouw 2 April 1994; Vermeulen, F. (1992). De laatste nachten van de vliegende brigades. NRC Handelsblad 22 Augustus 1992; De Kort, N. (2019). Op pad met 'groene boa's' in Limburg. NRC Handelsblad 8 April 2019. When I was trustee of Natuurmonumenten (for eight years), the Minister asked whether 'boswachters' could be issued with shrapnel vests and firearms, which we (and the boards of other organisations) turned down because it is the task and duty of the state to provide safety, security and maintenance of law and order. Yet, at present it becomes practice; see Anonymous (2019). BOA's gaan gewapend de natuur in. Rijnmond 2 December 2019; Anonymous (2019). Boa's dragen binnenkort steekwerend vest, maar niet iedereen mag er een. RTV Noord 15 November 2019.

[44] In many countries, access to justice at an independent court is fraught with difficulties and constraints; see, e.g.,: Francioni, F. (ed.). (2007). Access to Justice as a Human Right. Oxford University Press, Oxford, England. In the European Union it is a fundamental right: Harlow, C. (1999). Access to justice as a human right: the European convention and the EU. In: Alston, P., M.R. Bustelo \& J. Heenan (eds.). (1999). The EU and Human Rights (Vol. 1), pp. 187 - 214. Oxford University Press, Oxford, England even though there is still progress to be made: Greer, S., J. Gerards \& R. Slowe, R. (2018). Human Rights in the Council of Europe and the European Union: achievements, trends and challenges (Vol. 29). Cambridge University Press, Cambridge, England. India is a good example of how in reality access to justice is often effectively denied due to delays: Krishna, O. (2018). Structural reforms for overcoming delays in justice delivery. Journal of Constitutional Law and Jurisprudence 1: 32 - 41. Equally dangerous for citizens is the eagerness with which governments promulgate 'anti-terrorism legislation' under which safety of accused is hardly guaranteed and where arbitrary detention is rife. Here I give some references to different countries in which this is discussed: Hashmi, D., A. Saleem \& M. Shah (2016). The 'Protection of Pakistan Ordinance': limitations and prospects. Pakistan Journal of History and Culture 1 (2014): 65 - 84; Kwang, H. P. (2018). The new Prevention of Terrorism Act 2015 (POTA): a legal comment. Journal of Malaysian and Comparative Law 43: 15 - 34; Haq, I. (2019). Arbitrary detention: an introduction of USA and India. IAHRW International Journal of Social Sciences 7: 2071 - 2073. This shows that the defense of human rights is not only a thing done by NGO's from the western world as some may think. 
[45] At universities in the Netherlands, a regular professor is charged with guiding teaching and research of a group in a particular field of the sciences or humanities. So, when s/he is appointed by the board of a university, the appointment is in 'that academic field' and the 'full' or 'regular' professor is charged by this board to give that field guidance. This responsibility is termed 'leeropdracht' in Dutch (so, the charge to develop and guide the learning). The professorial position is named a 'leerstoel' ('chair' but perhaps more aptly translated as 'seat of learning'; so, when s/he speaks 'from his chair', s/he speaks 'ex cathedra'). When a professor retires in the Netherlands, $s$ /he hands in this charge to the board, who then can appoint a new professor in that academic field, and the outgoing professor can receive the rank of 'professor emeritus'. At some academic institutions, the awkward term 'chair group' has been coined; this term describes the group of lecturers, technicians, postdocs and doctoral students (and may include 'professors by special appointment') which is led by the 'regular professor' who holds the chair in the defined academic field. By rule and law, the 'regular professor' is responsible for the quality of the work of his or her staff. In that respect, there is little similarity with the concept of 'lab' and a 'chair' is not elected. 



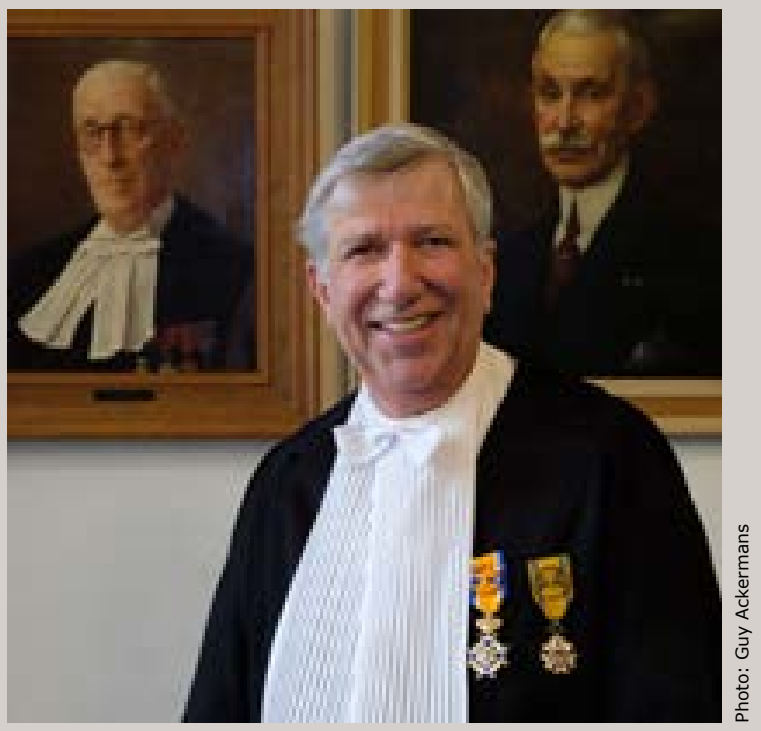

Prof.dr Herbert H.T. Prins

'Presently, there is much hot air spewed on the expected effect of climate change on the imminent extinction of animals and plants on our planet. Yet, land conversion, bush meat trade and poaching are problems that cause extinction now and not three hundred years in the future. Indeed, the Sixth Extinction is on our doorstep. Conservation action is needed on the ground, now. But modern conservation should embrace a deeper understanding of society and history but also technology, including Artificial Intelligence' 